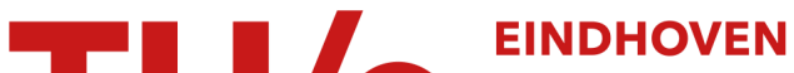

\section{A new method for the preparation of titanium-silicalite (TS-1)}

Citation for published version (APA):

Kraushaar, B., \& Hooff, van, J. H. C. (1988). A new method for the preparation of titanium-silicalite (TS-1). Catalysis Letters, 1(4), 81-84. https://doi.org/10.1007/BF00772769

DOI:

10.1007/BF00772769

Document status and date:

Published: 01/01/1988

\section{Document Version:}

Publisher's PDF, also known as Version of Record (includes final page, issue and volume numbers)

\section{Please check the document version of this publication:}

- A submitted manuscript is the version of the article upon submission and before peer-review. There can be important differences between the submitted version and the official published version of record. People interested in the research are advised to contact the author for the final version of the publication, or visit the $\mathrm{DOI}$ to the publisher's website.

- The final author version and the galley proof are versions of the publication after peer review.

- The final published version features the final layout of the paper including the volume, issue and page numbers.

Link to publication

\section{General rights}

Copyright and moral rights for the publications made accessible in the public portal are retained by the authors and/or other copyright owners and it is a condition of accessing publications that users recognise and abide by the legal requirements associated with these rights.

- Users may download and print one copy of any publication from the public portal for the purpose of private study or research.

- You may not further distribute the material or use it for any profit-making activity or commercial gain

- You may freely distribute the URL identifying the publication in the public portal.

If the publication is distributed under the terms of Article 25fa of the Dutch Copyright Act, indicated by the "Taverne" license above, please follow below link for the End User Agreement:

www.tue.nl/taverne

Take down policy

If you believe that this document breaches copyright please contact us at:

openaccess@tue.nl

providing details and we will investigate your claim. 


\title{
A NEW METHOD FOR THE PREPARATION OF TITANIUM-SILICALITE (TS-1)
}

\author{
B. KRAUSHAAR and J.H.C. VAN HOOFF \\ Laboratory of Inorganic Chemistry and Catalysis, Eindhoven University of Technology, \\ $5600 \mathrm{MB}$ Eindhoven, The Netherlands
}

Received 31 December 1987

Titanium-silicalite can be prepared by subsequent dealumination of ZSM-5 with hydrochloric acid and reaction with titaniumtetrachloride vapour at elevated temperatures. The titanium atoms are probably inserted into lattice vacancies which were formed upon acid leaching.

Titanium-silicalite (TS-1) is a titanium derivative of silicalite-1 (ZSM-5) which is assumed to contain titanium atoms in lattice positions replacing silicon atoms. This new material has promising catalytic properties in the field of oxidation reactions involving hydrogen peroxide [1-4]. The synthesis of TS-1 by hydrothermal reaction of tetraethylorthotitanates, a silicon source, tetrapropylammonium hydroxide and water has first beem claimed by Taramasso et al. [5].

Here, we describe an alternative route for the preparation of TS-1. The starting material is ZSM-5 with a framework $\mathrm{Si} / \mathrm{Al}$ ratio of 50 . The threefold treatment with $1 \mathrm{~N} \mathrm{HCl}$ solution at $353 \mathrm{~K}$ results in a material with $\mathrm{Si} / \mathrm{Al}$ ratio of about 2000. The reaction with $\mathrm{TiCl}_{4}$ is performed in a vertical quartz glass reactor. Prior to the reaction, the highly siliceous ZSM-5 is dried overnight at $723 \mathrm{~K}$ in a stream of purified and dried nitrogen. Then, nitrogen is saturated with $\mathrm{TiCl}_{4}$ at room temperature and passed through the reactor at temperatures between 673 and $773 \mathrm{~K}$. After completion of the reaction the product is purged with nitrogen at $773 \mathrm{~K}$ overnight and cooled down.

The results of the X-ray diffraction analyses are shown in Table 1 . The unit cell constants have decreased after dealumination of ZSM- 5 and have again increased after subsequent reaction with $\mathrm{TiCl}_{4}$. The increase in unit cell constants is more pronounced for products yielded at higher reaction temperatures. Since the Ti-O bond distance is larger than the Si-O bond distance these results give an indication for the insertion of $\mathrm{Ti}$ in the framework of highly siliceous ZSM-5. Furthermore, the changes from monoclinic unit cell symmetry in dealuminated ZSM-5 towards orthorhombic symmetry in the final products confirm this idea and are in agreement with the reported characteristics of hydrothermally prepared TS-1 [5]. 
Table 1

Crystal data *

\begin{tabular}{lll}
\hline Sample & framework symmetry & unit cell parameters [nm] \\
\hline ZSM-5 & orthorhombic & $a=2.0131$ \\
& & $b=1.9922$ \\
& & $c=1.3410$ \\
ZSM-5 after dealumination & monoclinic & $a=2.0110$ \\
& & $b=1.9890$ \\
& & $c=1.3386$ \\
dealuminated ZSM-5 after & orthorhombic & $a=2.0125$ \\
subsequent reaction with & & $b=1.9912$ \\
TiCl $_{4}$ (673 K) & $c=1.3401$ \\
dealuminated ZSM-5 after & orthorhombic & $a=2.0127$ \\
subsequent reaction with & & $b=1.9916$ \\
TiCl $_{4}$ (773 K) & & $c=1.3407$ \\
\hline
\end{tabular}

* The XRD patterns were measured on a Philips PW 7200 spectrometer using CuK $\alpha$ radiation. The unit cell parameters were obtained by a least-squares fit to the interplanar spacings of 10 strong reflexions.

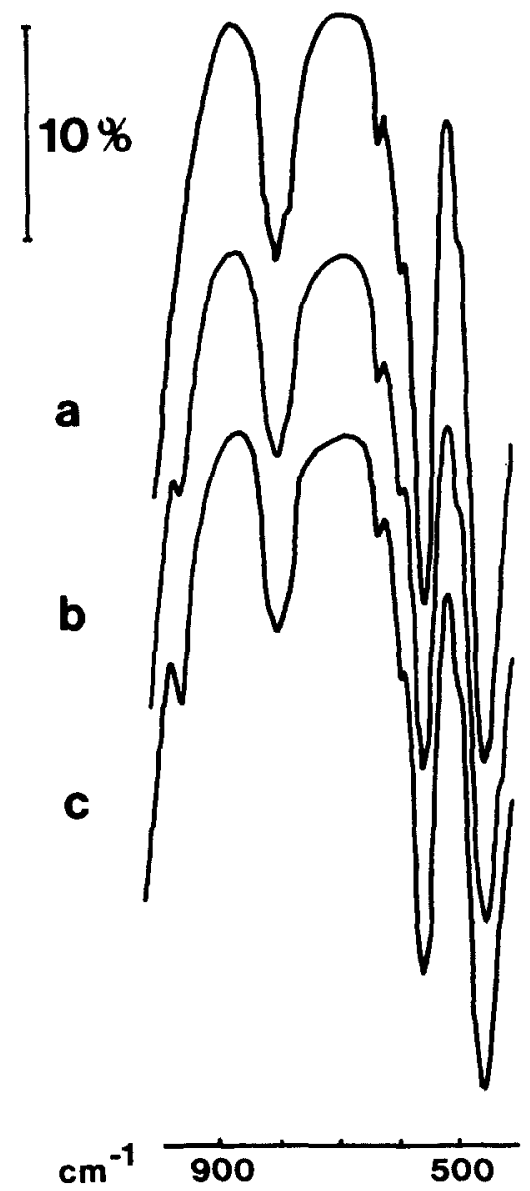

Fig. 1. IR spectra of (a) ZSM-5 after dealumination with hydrochloric acid, (b) dealuminated ZSM-5 after subsequent reaction with $\mathrm{TiCl}_{4}$ at $673 \mathrm{~K}$, (c) dealuminated ZSM-5 after subsequent reaction with $\mathrm{TiCl}_{4}$ at $773 \mathrm{~K}$. The spectra were obtained on a Hitachi 270-30 spectrometer using wafers of $0.6 \mathrm{mg}$ sample in $200 \mathrm{mg} \mathrm{KBr}$. 
The infrared spectra of samples treated with $\mathrm{TiCl}_{4}$ exhibit an adsorption band at $970 \mathrm{~cm}^{-1}$ which is absent in ZSM-5 or silicalite-1. It has been reported that this adsorption band is characteristic for TS- 1 and the intensity was found to be a function of the titanium content in the lattice [5]. Therefore, the spectra in fig. 1

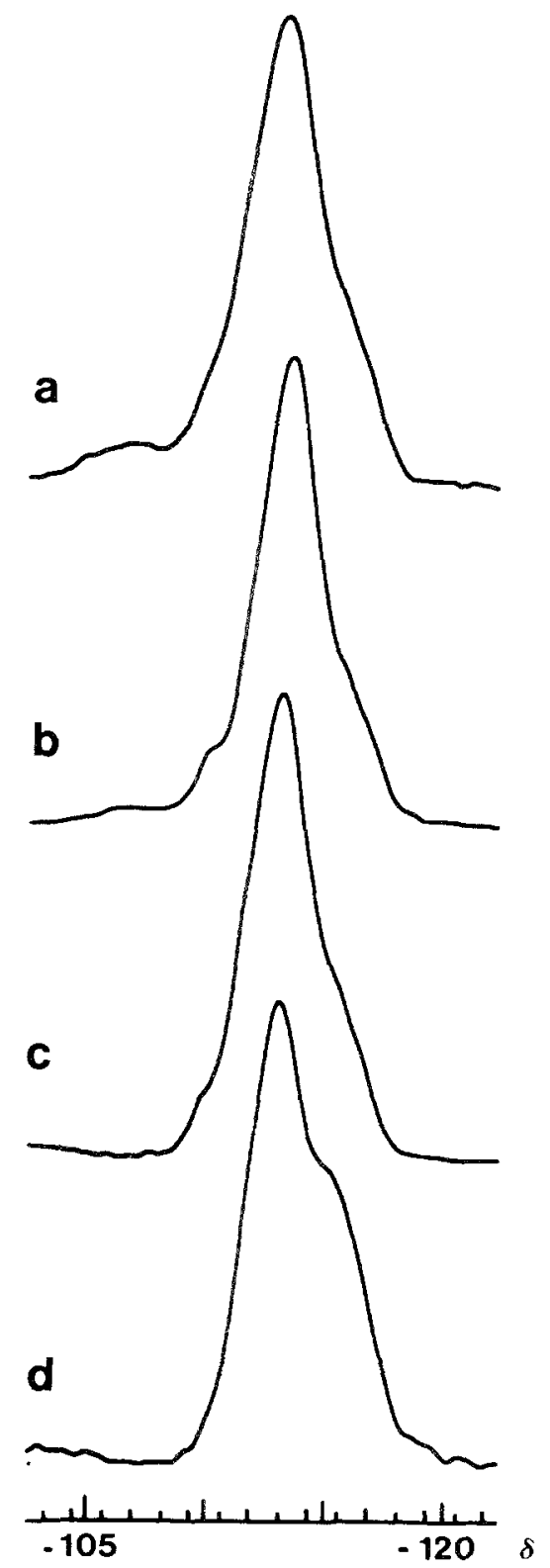

Fig. $2 .{ }^{29}$ Si MAS NMR spectra of (a) ZSM-5 starting material with $\mathrm{Si} / \mathrm{Al}=50$, (b) ZSM-5 after dealumination with hydrochloric acid, (c) dealuminated ZSM-5 after subsequent reaction with $\mathrm{TiCl}_{4}$ at $673 \mathrm{~K}$, (d) dealuminated ZSM-5 after subsequent reaction with $\mathrm{TiCl}_{4}$ at $773 \mathrm{~K}$. The spectra were obtained on a Bruker CXP-300 spectrometer at $59.63 \mathrm{MHz}$. 
give a further indication for the idea that higher reaction temperatures favour the insertion of Ti.

The ${ }^{29} \mathrm{Si}$ MAS NMR spectra [6] of ZSM-5 exhibit a signal at $-106 \mathrm{ppm}$ (relative to TMS) due to $\mathrm{Si}(3 \mathrm{Si}, \mathrm{Al})$ structural units in the starting material and due to $\mathrm{Si}(3 \mathrm{si}, \mathrm{OH})$ structural units in the dealuminated sample [fig. 2]. Crystallographically non-equivalent $\mathrm{Si}(4 \mathrm{Si})$ units are not distinguishable in the latter sample since the defect sites (silanol groups) affect the line width. As a result of the subsequent reaction with $\mathrm{TiCl}_{4}$ the ${ }^{29} \mathrm{Si}$ MAS NMR signal due to silanol groups decreases and the spectra exhibit an additional shoulder at about -115 ppm which has also been reported to be typically for TS-1 [7].

We conclude that acid leaching of ZSM-5 yields highly siliceous products with vacant $\mathrm{T}$-atom positions in the lattice which are available for the insertion of $\mathrm{Ti}$ atoms. The extend of the $\mathrm{Ti}$ insertion can be controlled by variation of the reaction temperature and, most probably, by the vapour pressure of $\mathrm{TiCl}_{4}$ and the reaction time.

\section{Acknowledgements}

The authors wish to thank C. Goossens for the preparation, dealumination and chemical analysis of the ZSM-5 samples.

\section{References}

[1] A. Esposito, C. Neri and F. Buonomo, Eur. Pat. 0102655 (1984).

[2] P. Roffia, M. Padovan, E. Moretti and G. De Alberti, Eur. Pat. 0208311 (1987).

[3] C. Neri, B. Anfossi, A. Esposito and F. Buonomo, Eur. Pat. 0100119 (1984).

[4] C. Neri and F. Buonomo, Eur. Pat. 0100117 (1984).

[5] M. Taramasso and B. Notari, U.S. Pat. 4,410,501 (1983).

[6] J.M. Thomas and J. Klinowski, Adv. in Catalysis 33 (1985) 199.

[7] G. Perego, G. Belussi, C. Corno, M. Taramasso, F. Buonomo and A. Esposito, in: Proc. 7th Int. Zeolite Conf. in Tokyo (Elsevier, Tokyo, 1980) p. 129. 